\title{
Digital modulation scheme in four dimensions based on wavelets
}

Jesús Mauricio Ramírez Viáfara, MSc(c). / jesusramirez@unicauca.edu.co

Harold Armando Romo Romero, MSc. / hromo@unicauca.edu.co

Grupo de Nuevas Tecnologías en Telecomunicaciones (GNTT)- Departamento de Telecomunicaciones- Facultad de Ingeniería Electrónica y Telecomunicaciones, Universidad del Cauca. Popayán,Colombia

ABSTRACT Information transmission over noisy channels in an efficient and reliable way is a primary objective of digital communication. In this article we propose a digital modulation scheme with a signal space of four dimensions to increase reliability. The signal space of this scheme is constructed on an orthonormal wavelet basis and its constellation is shaped by the eight farthest vertices of a hypercube centered on origin. For decisions based on minimum Euclidean distance, the proposed modulation scheme overcomes the performance against noise of that of quaternary quadrature amplitude modulation (4-QAM). This result allows us to say that a suitable design of constellation over a signal space with more than two dimensions can achieve a reduction in the bit error rate without a significant reduction of spectral efficiency.

KEYWORDS Constellation, spectral efficiency, orthonormal wavelet basis, wavelet.

\section{Esquema de modulación digital en cua-} tro dimensiones basado en wavelets

\begin{abstract}
RESUMEN Transmitir información de manera eficiente y confiable a través de canales ruidosos es un objetivo primario de la comunicación digital. En este artículo se propone un esquema de modulación con un espacio de señal de cuatro dimensiones que busca aumentar la confiabilidad de la transmisión. El espacio de señal de dicho esquema está construido con una familia wavelet ortonormal y los puntos de su constelación corresponden a los ocho vértices más lejanos de un hipercubo de cuatro dimensiones, centrado en el origen. Para decisiones basadas en distancia mínima Euclidiana, el esquema propuesto supera el desempeño frente al ruido de la modulación por amplitud en cuadratura de cuatro estados (4-QAM), con lo que se puede afirmar que un adecuado diseño de la constelación en un espacio de más de dos dimensiones permite reducir la tasa de error de bit sin comprometer significativamente la eficiencia espectral.
\end{abstract}

PALABRAS CLAVE Constelación, eficiencia espectral, familia wavelet ortonormal, wavelet. Esquema de modulação digital em qua-
tro dimensões baseado em wavelets

RESUMO Transmitir informações de forma eficiente e confiável através de canais ruidosos é o principal objetivo da comunicação digital. Neste artigo, é proposto um esquema de modulação com um espaço de sinal de quatro dimensões que procura aumentar a fiabilidade da transmissão. O espaço de sinal deste esquema está construído com uma família wavelet ortonormal e os pontos de sua constelação correspondem aos oito cantos mais distantes de um hipercubo de quatro dimensões centrado na origem. Para decisões baseadas em distância mínima euclidiana, o esquema proposto supera o desempenho em relação ao ruído da modulação de amplitude em quadratura com quatro estados (4-QAM), pelo que podemos dizer que um adequado projeto da constelação em um espaço de mais de duas dimensões poderá reduzir a taxa de erro de bit, sem comprometer significativamente a eficiência espectral.

PALAVRAS-CHAVE Constelação, eficiência espectral, família wavelet ortonormal, wavelet. 


\section{Introduction}

The design of modulation techniques that allows optimum data transfer between a source and a destination is a topic widely discussed in the context of digital communications. Digital modulation, defined as the process of representing a binary message by a suitable continuous-time signal for transmission over a noisy channel (Benvenutto \& Cherubini, 2002; Forney, 2005; Gallager, 2006), is usually designed around three objectives: high reliability (minimum probability of error), high efficiency (maximum speed of information in exchange for minimum consumption of bandwidth and power) and minimum complexity (especially in the detection process). However, it is practically impossible to build a modulation scheme that satisfies these purposes with equal effectiveness, so the solutions end up being engagement measures according to the needs and constraints of the environment where the communication is taking place (Noguchi, Daido \& Nossek, 1986; Forney \& Ungerboeck, 1998; Proakis, 2000; Haykin, 2002; Pursley, 2005).

Since the beginnings of information theory, the problem has been approached from two different perspectives, the first of which, called a limited bandwidth regime, considers a scenario with severe bandwidth restrictions in the channel, which leads to the spectral efficiency being prioritized over power efficiency. In this regard, multilevel modulation schemes (nonbinary) are typically used for pulse width modulation of M states (M-PAM), quadrature amplitude modulation of $\mathrm{M}$ states (M-QAM) or phase-shift keying of M states (M-PSK). The other perspective, called a power-limited regime, is applied in scenarios where the transmitter has a very limited amount of power, leading to the use of binary modulation schemes, together with channel coding techniques such as linear block coding or coding convolution. In the second case, the reliability is increased considerably, but the spectral efficiency suffers a noticeable drop. Additionally, an increase in the complexity of the detection by the use of channel coding is evidenced (Nyquist, 1928; Hartley, 1928; Shannon, 1948; Gallager, 1968; Cover \& Thomas, 2006).

When no channel coding is used, there is no modulation scheme that reaches a probability of error in detection less than $Q\left(\sqrt{2 E_{b} / N_{0}}\right)$, where $E_{b} / N_{0}$ is the ratio of bit energy to spectral noise power density and $Q(\cdot)$ is the standard normal cumulative distribution complemen-

\section{Introducción}

El diseño de técnicas de modulación que permitan una óptima transferencia de datos entre una fuente y un destino es un tema ampliamente tratado en el contexto de las comunicaciones digitales. La modulación digital, definida como el proceso de representar un mensaje binario mediante una señal de tiempo continuo conveniente para la transmisión por un canal ruidoso(Benvenutto \& Cherubini, 2002; Forney, 2005; Gallager, 2006), se suele diseñar en torno a tres objetivos, a saber: máxima confiabilidad (mínima probabilidad de error), máxima eficiencia (máxima velocidad de información a cambio de mínimo consumo de ancho de banda y potencia) y mínima complejidad (especialmente en el proceso de detección). No obstante, es prácticamente imposible construir un esquema de modulación que satisfaga con igual efectividad tales propósitos, por tanto, las soluciones terminan siendo medidas de compromiso según las necesidades y limitaciones del entorno donde se lleva a cabo la comunicación (Noguchi, Daido \& Nossek, 1986; Forney \& Ungerboeck, 1998; Proakis, 2000; Haykin, 2002; Pursley, 2005).

Desde los inicios de la teoría de la información, el problema se ha enfocado desde dos perspectivas distintas, la primera, denominada régimen limitado en ancho de banda, considera un escenario con fuertes restricciones de ancho de banda en el canal, lo que motiva a priorizar la eficiencia espectral por sobre la eficiencia en potencia. En ese sentido, se suelen usar esquemas de modulación multinivel (no binarios) como modulación por amplitud de pulsos de M estados (M-PAM), modulación por amplitud en cuadratura de $\mathrm{M}$ estados (M-QAM), o modulación por desplazamiento de fase de M estados (M-PSK). La otra perspectiva, denominada régimen limitado en potencia, se aplica en escenarios donde el transmisor dispone de una cantidad muy limitada de potencia, lo que lleva a utilizar esquemas de modulación binarios, acompañados de técnicas de codificación de canal tales como codificación bloque lineal o codificación convolucional. En el segundo caso, la confiabilidad aumenta considerablemente, pero la eficiencia espectral sufre una caída notoria. Adicionalmente, se evidencia un incremento en la complejidad de la detección debido al uso de codificación de canal (Nyquist, 1928; Hartley, 1928; Shannon, 1948; Gallager, 1968; Cover \& Thomas, 2006).

Cuando no se emplea codificación de canal, no existe esquema de modulación alguno que alcance una probabilidad de error en la detección inferior a $Q\left(\sqrt{2 E_{b} / N_{0}}\right)$, donde $E_{b} / N_{0}$ es la relación energía de bit a densidad espectral de potencia de ruidoy $Q\left({ }^{*}\right)$ es la función complementaria de distribución acumulativa normal estándar ${ }^{1}$ (Benvenutto \& Cherubini, 2002; Forney et al, 1998; Forney, 2005; Gallager, 2006).Al considerar un canal cuyo único efecto degradante es el ruido blanco Gaussiano aditivo[AWGN], algunas modulaciones como 2-PAM, 2-PSK y 4-QAM (o 4-PSK) logran ese valor mínimo de probabilidad de error. Desde el punto de vista del espacio de señal, la principal razón que evita que se supere dicho um-

$$
Q(x)=\frac{1}{\sqrt{2 \pi}} \int_{x}^{\infty} e^{-u^{2} / 2} d u .
$$


bral de desempeño es la relación existente entre la distancia mínima Euclidiana de la constelación y la energía promedio de bit, la cual, para constelaciones en una y dos dimensiones, está acotada por:

$$
d \leq 2 \sqrt{E_{b}}, \quad(1)
$$

donde $d$ es la distancia mínima de la constelación y $E_{b}$ es la energía promedio de bit (Forney, 2005; Gallager, 2006). Por este motivo, el objetivo de la presente investigación es aumentar $d$ en términos de $E_{b}$, para lo cual es necesario definir un espacio de señal con más de dos dimensiones, lo que a su vez requiere el uso de más de dos funciones simultáneas y mutuamente ortogonales por periodo de símbolo.

Como es bien sabido, los espacios de señal soportados sobre funciones sinusoidales permiten obtener, a lo sumo, dos funciones ortogonales por periodo de símbolo (tal como ocurre en M-QAM y M-PSK).Por otra parte, las familias wavelet ortonormales se constituyen en una buena alternativa para soportar un espacio de señal con más de dos dimensiones, pues poseen características de ortogonalidad, simultaneidad y localización espectral que no poseen las funciones sinusoidales tradicionales (Livingston, 1996; Lindsey \& Medley, 1996; Lindsey, 1997), por tanto, se las utiliza como conjunto base del esquema de modulación propuesto. La idea clave es utilizar una wavelet diferente para representar cada dimensión de la constelación. En ese sentido, el principal aporte de este artículo es proponer un esquema de modulación con una constelación en cuatro dimensiones, soportada por un conjunto base de funciones wavelet pertenecientes a una familia ortonormal, y evaluar tanto su eficiencia espectral como su desempeño frente al ruido. Con ello se busca superar el umbral de probabilidad de error de la modulación no codificada tradicional sobre canales AWGN. El artículo está organizado de la siguiente manera: en la sección 2 se describe la metodología empleada para diseñar esquema de modulación, en la sección 3 se muestran los resultados más relevantes de las simulaciones y en la sección 4 se analizan los resultados y se finaliza el artículo con algunas conclusiones.

\section{Metodología}

\subsection{Descripción matemática del esquema de modulación}

La constelación, $\mathcal{A}$, del esquema de modulación propuesto está constituida por 8 símbolos $^{2}$ de 4 dimensiones (cada uno transporta 3 bits), obtenidos mediante la regla de mapeo de la TABLA 1.

El superíndice []$^{T}$ representa transposición matricial.

Como puede observarse, la constelación está formada por 8 de los 16 vértices de un hipercubo de lado $2 \alpha$ centrado en el origen del espacio $\mathbb{R}^{4}$. Los vértices elegidos son aquellos puntos que se encuentran separados entre sí una distancia $2 \sqrt{2} \alpha$.

Por su parte, el conjunto base, en el ${ }^{n}$-ésimo periodo de símbolo, está descrito por un vector $\boldsymbol{\Psi}_{n}(t)$ de 4 funciones ortonor-

2. En este artículo, la palabra símbolo corresponde a una N-tupla de números reales, la cual se representa geométricamente como un punto en el espacio N-dimensional. Cada símbolo contiene la información de $\log _{z} M$ bits, donde $M$ es el tamaño de la constelación. tary function ${ }^{1}$ (Benvenutto \& Cherubini, 2002; Forney et al., 1998; Forney, 2005; Gallager, 2006). When considering a channel of which the only degrading effect is the additive white Gaussian noise [AWGN], some modulation such as 2-PAM, 2-PSK and 4-QAM (or 4-PSK) achieves that minimum error probability.

From the standpoint of the signal space, the main factor that prevents the performance threshold being exceeded is the relation between the minimum Euclidean distance of the constellation and the average bit energy, which, for constellations of one and two dimensions, is bounded by:

$$
d \leq 2 \sqrt{E_{b}}, \quad(1)
$$

where $d$ is the minimum distance of the constellation and $E_{b}$ is the average bit energy (Forney, 2005; Gallager, 2006). For that reason, the objective of this research is to increase $d$ in terms of $E_{b}$, for which it is necessary to define a signal space with more than two dimensions, which in turn requires the use of more than two simultaneous mutually orthogonal functions for the symbol period.

As is well known, the signal spaces supported on sinusoidal functions allow us to obtain, at most, two orthogonal functions for the symbol period (as occurs in M-QAM and M-PSK). Furthermore, orthonormal wavelet families constitute a good alternative to support a signal space with more than two dimensions, because they have characteristics of orthogonality, simultaneity, and spectral localization that lacks the traditional sinusoidal functions (Livingston, 1996; Lindsey \& Medley, 1996; Lindsey, 1997). Therefore, they are used as the base set of the proposed modulation scheme. The key idea is to use a different wavelet to represent each dimension of the constellation. In this regard, the main contribution of this paper is to propose a modulation scheme with a constellation in four dimensions, supported by a wavelet functions base set belonging to an orthonormal family, and evaluate both the spectral efficiency and performance against noise. It seeks to overcome the error probability threshold of traditional uncoded modulation over AWGN channels. The paper is organized as follows: section 2 describes the methodology used to design the modulation scheme, in section 3 the most relevant results of the simulations are shown and in section 4 the results are analyzed and the article ends with some conclusions.

$$
\text { 1. } Q(x)=\frac{1}{\sqrt{2 \pi}} \int_{x}^{\infty} e^{-u^{2} / 2} d u \text {. }
$$




\section{Methodology}

\subsection{Mathematical description of the modulation scheme}

The constellation, $\mathcal{A}$, from the modulation scheme proposed is constituted by 8 symbols $^{2}$ of 4 dimensions (each one transports 3 bits) obtained by the mapping rule of TABLE $\mathbf{1}$.

The superscript $[\cdot]^{T}$ represents matrix transposition.

As can be observed, the constellation is formed by 8 of the 16 vertices of a hypercube with sides $2 \alpha$ centered in the origin of the space $\mathbb{R}^{4}$. The chosen vertices are those points which are separated from each other by a distance equal to $2 \sqrt{2} \alpha$.

For its part, the base set, in the $n$-th period of the symbol, is described by a $\boldsymbol{\Psi}_{n}(t)$ vector of 4 orthonormal functions (one for each dimension of the constellation), defined as follows:

$$
\boldsymbol{\Psi}_{n}(t)=\left[\begin{array}{llll}
\phi_{n}^{(m)}(t) & \psi_{n}^{(m)}(t) & \psi_{2 n}^{(m+1)}(t) & \psi_{2 n+1}^{(m+1)}(t)
\end{array}\right]^{T}(2)
$$

where $\psi(t)$ and $\phi(t)$ are respectively the functions mother wavelet and scaling wavelet of an orthonormal wavelet family, while $m$ and $n$ are the scale coefficients and translation. Likewise, $\psi_{n}^{(m)}(t)=\sqrt{2^{m}} \psi\left(2^{m} t-n\right)$ is the wavelet function of scale $m$, located in the instant $2^{-m} n$. In the same way, $\phi_{n}^{(m)}(t)=\sqrt{2^{m}} \phi\left(2^{m} t-n\right)$ is the scaling function of scale $m$, located in $2^{-m} n$ (Daubechies, 1988, 1990, 1992; Wornell \& Oppenheim, 1992; Mallat, 1998). In this way, the symbol rate will be $1 / T=2^{m}$ baud. Note that the functions of the vector $\boldsymbol{\Psi}_{n}(t)$ are orthogonal to each other and also orthogonal to their own versions displaced by $n T$ seconds, that is:

$$
\int_{-\infty}^{\infty} \boldsymbol{\Psi}_{n}(t) \boldsymbol{\Psi}_{k}(t) d t=\mathbf{I}_{4} \delta[n-k],
$$

where $\mathbf{I}_{4}$ is the identity matrix $4 \times 4$ and $\delta[\cdot]$ is the Kronecker delta function.

Suppose that you want to transmit a $\left\{b_{i}\right\}_{i=0}^{K-1}$ sequence of $K$ equiprobable and independent bits. By using the mapping rule of TABLE 1 , we obtain a sequence of $K / 3$ symbols, $\left\{\mathbf{X}_{n}\right\}_{n=0}^{K / 3-1}$, where $\mathbf{X}_{n} \in \mathcal{A}, \forall n=0,1, \ldots, \frac{K}{3}-1$ . Then, the modulated signal, $X(t)$, will be the aleatory process given by:

$$
X(t)=\sum_{n=0}^{\frac{K}{3}-1}\left[\mathbf{X}_{n}\right]^{T} \Psi_{n}(t) .
$$

2. In this article, the word symbol corresponds to an n-tuple of real numbers, which is represented geometrically as a point in the $\mathrm{N}$-dimensional space. Each symbol contains the information of $\log _{2} M$ bits, where $M$ is the size of the constellation.
Table 1. Mapping rule of the proposed modulation scheme / Regla de mapeo del esquema de modulación propuesto.

\begin{tabular}{cc}
$\begin{array}{c}\text { Binary sequence / } \\
\text { Secuenciabinaria }\end{array}$ & Symbol / Simbolo \\
\hline 000 & {$\left[\begin{array}{llll}-\alpha & -\alpha & -\alpha & -\alpha\end{array}\right]^{T}$} \\
001 & {$\left[\begin{array}{llll}-\alpha & -\alpha & +\alpha & +\alpha\end{array}\right]^{T}$} \\
010 & {$\left[\begin{array}{llll}-\alpha & +\alpha & -\alpha & +\alpha\end{array}\right]^{T}$} \\
011 & {$\left[\begin{array}{llll}-\alpha & +\alpha & +\alpha & -\alpha\end{array}\right]^{T}$} \\
100 & {$\left[\begin{array}{llll}+\alpha & -\alpha & -\alpha & +\alpha\end{array}\right]^{T}$} \\
101 & {$\left[\begin{array}{llll}+\alpha & -\alpha & +\alpha & -\alpha\end{array}\right]^{T}$} \\
110 & {$\left[\begin{array}{llll}+\alpha & +\alpha & -\alpha & -\alpha\end{array}\right]^{T}$} \\
111 & {$\left[\begin{array}{llll}+\alpha & +\alpha & +\alpha & +\alpha\end{array}\right]^{T}$} \\
\hline
\end{tabular}

males (una por cada dimensión de la constelación), definidas de la siguiente forma:

$$
\boldsymbol{\Psi}_{n}(t)=\left[\begin{array}{llll}
\phi_{n}^{(m)}(t) & \psi_{n}^{(m)}(t) & \psi_{2 n}^{(m+1)}(t) & \psi_{2 n+1}^{(m+1)}(t)
\end{array}\right]^{T}
$$

donde $\psi(t)$ y $\phi(t)$ son las respectivas funciones wavelet madre y scaling madre de una familia wavelet ortonormal, mientras que

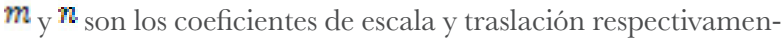
te. Así mismo $\psi_{n}^{(m)}(t)=\sqrt{2^{m}} \psi\left(2^{m} t-n\right)$ es la función wavelet de escala $m$, localizada en el instante $2^{-m} n$. De la misma forma, $\phi_{n}^{(m)}(t)=\sqrt{2^{m}} \phi\left(2^{m} t-n\right)$ es la función scaling de escala $m$, localizada en $2^{-m} n$ (Daubechies, 1988, 1990, 1992; Wornell \& Oppenheim, 1992; Mallat, 1998). De esta manera, la velocidad de símbolo será $1 / T=2^{m}$ baud. Nótese que las funciones del vector $\Psi_{n}(t)$ son ortogonales entre sí y también son ortogonales a sus propias versiones desplazadas en $n T$ segundos, esto es:

$$
\int_{-\infty}^{\infty} \boldsymbol{\Psi}_{n}(t) \boldsymbol{\Psi}_{k}(t) d t=\mathbf{I}_{4} \delta[n-k],
$$

donde $\mathbf{I}_{4}$ es la matriz identidad $4 \times 4$ y $\delta[\cdot]$ es la función delta Kronecker.

Supóngase que se desea transmitir una secuencia $\left\{b_{i}\right\}_{i=0}^{K-1}$ de $K$ bits equiprobables e independientes. Al aplicar la regla de mapeo de la TABLA 1 se obtiene una secuencia de $K / 3$ símbolos, $\left\{\mathbf{X}_{n}\right\}_{n=0}^{K / 3-1}$, donde $\mathbf{x}_{n} \in \mathcal{A}, \forall n=0,1, \ldots, \frac{K}{3}-1$.Luego, la señal modulada, $X(t)$, será el proceso aleatorio dado por:

$$
X(t)=\sum_{n=0}^{\frac{K}{3}-1}\left[\mathbf{X}_{n}\right]^{T} \Psi_{n}(t)
$$

En su paso por el canal, la señal modulada $X(t)$ se contamina con un proceso de ruido AWGN, $Z(t)$, de media cero y densidad espectral de potencia $N_{0} / 2$, lo que produce una señal $Y(t)$ a la entrada del receptor (salida del canal) dada por Forney (2005) y Gallager (2006):

$$
Y(t)=X(t)+Z(t)
$$

Una vez en el receptor, se procede a correlacionar la señal recibida con el conjunto base(en cada periodo de símbolo), con lo que se obtiene una secuencia de vectores, $\left\{\mathbf{Y}_{n}\right\}_{n=0}^{K / 3-1}$, dada por:

http://www.icesi.edu.co/revistas/index.php/sistemas telematica 


$$
\mathbf{Y}_{n}=\int_{-\infty}^{\infty} Y(t) \Psi_{n}(t) d t
$$

Como

$$
Y(t)=\sum_{m=0}^{\frac{K}{2}-1}\left[\mathbf{X}_{m}\right]^{T} \Psi_{m}(t)+Z(t),
$$

$\int_{-\infty}^{\infty} \Psi_{n}(t) \Psi_{m}(t) d t=\mathbf{I}_{4} \delta[n-m]$, la secuencia de vectores $\mathbf{Y}_{n}$ quedará de la forma:

$$
\mathbf{Y}_{n}=\mathbf{X}_{n}+\mathbf{Z}_{n}
$$

donde $\mathbf{Z}_{n}=\int_{-\infty}^{\infty} Z(t) \Psi_{m}(t) d t$ es un vector de 4 variables aleatorias Gaussianas independientes e idénticamente distribuidas (iid), de media cero y varianza $N_{0} / 2$. De esa forma, el canal continuo AWGN se reduce al modelo de tiempo discreto de la ecuación (7) (Forney, 2005). Dado que los bits del mensaje son equiprobables e independientes, los símbolos de la constelación también son equiprobables e independientes, por tanto, la regla de decisión que minimiza la probabilidad de error en la detección de cada símbolo es la regla de distancia mínima Euclidiana. Dicha regla consiste en elegir el símbolo de la constelación más cercano geométricamente al vector recibido, $\mathbf{Y}_{n}$, esto es (Forney et al, 1998; Forney, 2005; Gallager, 2006):

$$
\widehat{\mathbf{X}}_{n}=\underset{\mathbf{a}_{m} \in \mathcal{A}}{\arg \min _{n}}\left\|\mathbf{Y}_{n}-\mathbf{a}_{m}\right\|,
$$

donde $\widehat{\mathbf{x}}_{n}$ es el símbolo estimado y detectado en el periodo $n$ -ésimo de símbolo y $\|\cdot\|$ es el operador de norma Euclidiana. Finalmente, se hace un proceso de mapeo inverso, obteniéndose una secuencia de bits $\left\{\hat{b}_{i}\right\} \hat{i=0}=0$ que corresponde al mensaje recuperado. La probabilidad de error de bit (BEP) estará dada por:

$$
\operatorname{Pr}\{\mathcal{E}\}=\operatorname{Pr}\left\{\hat{b}_{i} \neq b_{i}\right\}, \quad i=0,1,2, \ldots, K-1 .(9)
$$

\subsection{Diseño del transmisor y receptor}

A partir de la ecuación (4) se puede deducir que el proceso de modulación consiste en realizar una transformada inversa wavelet a dos escalas sobre los símbolos que se quieren transmitir, es decir, asumir que dichos símbolos corresponden a los coeficientes wavelet de la señal modulada. Por su parte, el proceso de demodulación consiste en realizar una transformada directa wavelet sobre la señal ruidosa que sale del canal. Desde el punto de vista computacional y de implementación, las operaciones mencionadas se pueden llevar a cabo a través de los algoritmos de Mallat, a saber, el algoritmo transformada rápida inversa wavelet [IFWT] para la etapa de modulación y el algoritmo transformada rápida wavelet [FWT] para la etapa de demodulación. De esta manera, se obtiene una aproximación muestral de la señal modulada. Para generar la señal en tiempo continuo basta con aplicar un filtro interpolador a la salida del bloque IFWT. Si el algoritmo IFWT tiene una cantidad suficiente de iteraciones (4 o más), la frecuencia de muestreo estará muy por encima de la frecuencia crítica de Nyquist, por tanto, el filtro interpolador podrá implementarse con cierta flexibilidad. Por su parte, a la entrada del receptor se requiere un dispositivo de muestreo con una frecuencia $2^{r} / T$, donde ${ }^{r}$ es el número de iteraciones del algoritmo IFWT. Enseguida de éste se aplica el algoritmo FWT para obtener los coeficientes wavelet que representan las diferentes dimensiones de la constelación. Finalmente se in-
In passing through the channel, the modulated signal $X(t)$ is contaminated with an AWGN noise process, $Z(t)$, of median zero and power spectral density $N_{0} / 2$, which produces a $Y(t)$ signal at the input of the receiver (channel's output) given by Forney (2005) and Gallager (2006):

$$
Y(t)=X(t)+Z(t)
$$

Once in the receiver, the received signal is then correlated with the base set (in each symbol period), and thereby a sequence of vectors, $\left\{\mathbf{Y}_{n}\right\}_{n=0}^{K / 3-1}$, is obtained, given by:

$$
\mathbf{Y}_{n}=\int_{-\infty}^{\infty} Y(t) \Psi_{n}(t) d t
$$

Because $\quad Y(t)=\sum_{m=0}^{\frac{K}{3}-1}\left[\mathbf{X}_{m}\right]^{T} \Psi_{m}(t)+Z(t), \quad$ and $\int_{-\infty}^{\infty} \Psi_{n}(t) \Psi_{m}(t) d t=\mathbf{I}_{4} \delta[n-m]$, the sequence of vectors $\mathbf{Y}_{n}$ will have the form:

$$
\mathbf{Y}_{n}=\mathbf{X}_{n}+\mathbf{Z}_{n}
$$

where $\mathbf{Z}_{n}=\int_{-\infty}^{\infty} Z(t) \Psi_{m}(t) d t$ is a vector of 4 independent and identically distributed (iid) Gaussian aleatory variables, of median zero and variance $N_{0} / 2$. In this way, the continuous AWGN channel is reduced to the discrete time model of equation (7) (Forney, 2005). Given that the bits of the message are equiprobable and independent, the decision rule that minimizes the error probability in detecting each symbol is therefore the minimum Euclidean distance. This rule consists in choosing the symbol of the constellation that is geometrically closest to the received vector, $\mathbf{Y}_{n}$, that is (Forney et al., 1998; Forney, 2005; Gallager, 2006):

$$
\widehat{\mathbf{X}}_{n}=\underset{\mathbf{a}_{m} \in \mathcal{A}}{\arg \min _{n}}\left\|\mathbf{Y}_{n}-\mathbf{a}_{m}\right\|
$$

where $\widehat{\mathbf{X}}_{n}$ is the estimated and detected symbol in the n-th period of time and $\|\cdot\|$ is the Euclidean norm operator. Finally, an inverse mapping process is done, obtaining a bits sequence $\left\{\hat{b}_{i}\right\}_{i=0}^{K-1}$ which corresponds to the recovered message. The bit error probability (BEP) will be given by:

$$
\operatorname{Pr}\{\mathcal{E}\}=\operatorname{Pr}\left\{\hat{b}_{i} \neq b_{i}\right\}, \quad i=0,1,2, \ldots, K-1 .(9)
$$

\subsection{Design of the transmitter and receiver}

From equation (4) it can be deduced that the modulation process consists in performing an inverse wavelet transform to two scales on the symbols to be transmitted, that is, assuming that these symbols correspond to the wavelet coefficients of the modulated signal. Meanwhile, 
the demodulation process consists in performing a wavelet direct transform on the noisy signal which comes out through the channel. From the computational viewpoint and implementation, the mentioned operations can be carried out through Mallat algorithms, in other words, the inverse fast wavelet transform algorithm [IFWT] for the modulation phase and the fast wavelet transform algorithm [FWT] for the demodulation phase. Thus, one sample approximation of the modulated signal is obtained. To generate the signal in continuous time simply, it is enough to apply an interpolator filter to the IFWT block output. If the IFWT algorithm has a sufficient amount of iterators (4 or more), the sampling frequency will be well above the Nyquist critical frequency, and the interpolator filter can therefore be implemented with a certain flexibility. Meanwhile, at the input of the receiver a sampling device is required with a frequency of $2^{r} / T$, where $r$ is the number of iterations of the algorithm IFWT. After that, the algorithm FWT is applied to obtain the wavelet coefficients that represent the different dimensions of the constellation. Finally, a decision device / de-mapping is introduced to generate an estimate of the transmitted binary sequence according to a decision rule of minimum Euclidean distance. Figures 1 and 2 show the transmitter and receiver designs for the proposed modulation scheme.

\section{Results}

\subsection{Performance parameters}

The parameters that will be taken into account to evaluate the performance of the proposed modulation scheme, through simulation, are the following:

\section{- Bit Error Rate [BER]:}

This is defined as the quotient between the number of bits erroneously detected at the destination and the total number of transmitted bits, that is: troduce un dispositivo de decisión/de-mapeo que genera una estimación de la secuencia binaria transmitida de acuerdo a una regla de decisión de distancia mínima Euclidiana. En las Figuras 1 y 2 se muestran los diseños del transmisor y receptor para el esquema de modulación propuesto.

\section{Resultados}

\subsection{Parámetros de desempeño}

Los parámetros que serán tenidos en cuenta para evaluar el desempeño del esquema de modulación propuesto, mediante simulación, son los siguientes:

- Tasa de Error de Bit [VER]:

Se define como el cociente entre el número de bits detectados erróneamente en el destino y el número total de bits transmitidos, esto es:

$$
B E R=\frac{\text { Number of bits erroneously detected }}{\text { Number of transmitted bits }}
$$

La BER corresponde a la frecuencia relativa del evento $\left\{\hat{b}_{i} \neq b_{i}\right\}$, por tanto, al transmitirse una cantidad de bits arbitrariamente grande, será una estimación muy aproximada de la probabilidad de error de bit $(\mathrm{BEP}), \operatorname{Pr}\left\{\hat{b}_{i} \neq b_{i}\right\}$.

\section{- Eficiencia espectral $(\boldsymbol{\rho})$ :}

Se define como la razón entre la velocidad de transmisión de bits, $\boldsymbol{R}_{\boldsymbol{b}}$, (en b/s) y el ancho de banda ocupado por la señal modulada, $W$, (en Hz), esto es:

$$
\rho=\frac{R_{b}}{W}
$$

Para una constelación de $M$ símbolos, la velocidad de transmisión binaria está dada por Gallager (2006):

$$
R_{b}=\frac{1}{T} \log _{2} M,(12)
$$

donde $T$ es el tiempo transturrido entre la emisión de 2 símbolos consecutivos (bloques de 3 bits), por tanto, el periodo de bit, $T_{b}$, está dado por $T_{b}=T / \log _{2} M$. 
En el esquema de modulación propuesto, $M=8$, así $R_{b}=1 / T_{b}=3 / T$.

Para las simulaciones del esquema de modulación propuesto, se ha definido como ancho de banda la longitud del intervalo de frecuencia donde se concentra el 99\% de la energía de la señal modulada, esto es:

$$
\frac{\int_{-W}^{W} S_{X X}(f) d f}{\int_{-\infty}^{\infty} S_{X X}(f) d f}=0.99,
$$

donde $S_{X X}(f)$ esla densidad espectral de potencia del proceso aleatorio $X(t)$ (Pursley, 2005).

\subsection{Resultados de la simulación}

En Figura 3 se muestra una sección de la señal modulada, obtenida por simulación ${ }^{3}$ y su correspondiente espectro con diferentes familias wavelet. En las gráficas del lado izquierdo, el eje horizontal representa el tiempo normalizado (respecto a $T$ ) y el eje vertical el valor de la señal modulada (en volt, volt $/ \mathrm{m}, \mathrm{amp} / \mathrm{m}$, etc., dependiendo del medio de transmisión). En las figuras del lado derecho, el eje horizontal corresponde a la frecuencia normalizada (respecto a la tasa de símbolo, 1/T) y el eje horizontal representa la densidad espectral de potencia de la señal modulada (en watt/ $\mathrm{Hz}$ ). En dicha figura se puede notar que el espectro de la señal modulada tiene carácter pasa-bajas en los tres casos expuestos. Por otro lado, el ancho de banda ocupado con la wavelet discreta de Meyer (dmey) es notablemente menor al ocupado con la wavelet de Haar. Adicional a ello, la potencia espectral se distribuye de una forma mucho más equitativa con la wavelet de Meyer.

En la TABLA 2 se consignan los resultados en eficiencia espectral logrados con diferentes familias wavelet.

En Figura 4 se muestra la curva de desempeño de la BER vs $E_{b} / N_{0}$ para el esquema de modulación planteado (WavP 8S-4D). También se muestra la curva correspondiente al esquema 4-QAM (que coincide con la curva de los esquemas 2-PAM y 2-PSK).

En la TABLA 3 se muestra comparativamente el desempeño del esquema planteado (WavP 8S-4D) respecto a algunas modulaciones tradicionales. La ganancia de codificación que aparece en la tabla corresponde a la cantidad de decibeles en que puede reducirse la $E_{b} / N_{0}$ para lograr una BER de ${ }^{10^{-5}}$ respecto al esquema 2-PAM (Forney, 2005). Para la eficiencia espectral de los esquemas tradicionales que aparecen en la tabla, se ha considerado el uso de filtros de raíz cuadrada de coseno alzado (SR-RCF), con factor roll-off de 0.25 (Noguchi, 1986).

\section{Discusión y conclusiones}

\subsection{Análisis de resultados}

La Figura 4 muestra que el desempeño frente al ruido del esquema de modulación propuesto es superior al de las modulaciones 2-PAM, 2-PSK y 4-QAM, es decir, requiere menor cantidad de relación $E_{b} / N_{0}$ para lograr un cierto valor de BER. Este resultado demuestra que es posible superar el desempeño

\footnotetext{
3. En cada iteración de la simulación se transmitieron $10^{\circ}$ bits equiprobables e independientes. Las variables de entrada de la simulación fueron la relación Eb/No a la entrada del receptor y el tipo de wavelet. Por su parte, las variables de salida fueron la tasa de error de bit (BER) y el ancho de banda al 99\%. Los resultados de la figura 4 corresponden al promedio de 10 iteraciones independientes sobre cada valor de $\mathrm{Eb} / \mathrm{No}$.
}

\section{$B E R=\frac{\text { Number of bits erroneously detected }}{\text { Number of transmitted bits }}$.}

The BER corresponds to the relative frequency of the event $\left\{\hat{b}_{i} \neq b_{i}\right\}$; thereby, when transmitting an arbitrary big amount of bits, $\operatorname{Pr}\left\{\hat{b}_{i} \neq b_{i}\right\}$ will be a very approximate estimation of the bit error probability.

\section{- Spectral efficiency $(\rho)$ :}

This is defined as the ratio between the bits transmission speed, $R_{b}$, (in $\mathrm{b} / \mathrm{s}$ ) and the bandwidth occupied by the modulated signal, $W$, (in $\mathrm{Hz}$ ), that is:

$$
\rho=\frac{R_{b}}{W} \text {. }
$$

For a constellation of $M$ symbols, the binary transmission speed is given by Gallager (2006):

$$
R_{b}=\frac{1}{T} \log _{2} M,
$$

where $T$ is the elapsed time between the emission of 2 consecutive symbols ( 3 bits blocks); therefore, the period of the bit, $T_{b}$, is given by: $T_{b}=T / \log _{2} M$.

In the proposed modulation scheme, $M=8$, así $R_{b}=1 / T_{b}=3 / T$.

For the simulation of the proposed modulation scheme, the bandwidth has been defined as the frequency interval length where 99\% of the energy of the modulated signal is concentrated; that is:

$$
\frac{\int_{-W}^{W} S_{X X}(f) d f}{\int_{-\infty}^{\infty} S_{X X}(f) d f}=0.99,
$$

where $S_{X X}(f)$ is the power spectral density of the aleatory process $X(t)$ (Pursley, 2005).

\subsection{Results of the simulation}

Figure 3 shows a section of the modulated signal, obtained by simulation ${ }^{3}$ and the corresponding spectrum with various wavelet families. In the graphs on the left, the horizontal axis represents the normalized time (with respect to $\mathrm{T}$ ) and the vertical axis the value of the modulated signal (in volt volt/m, amp/m, etc., depending on the transmission medium). In the figures on the right side, the horizontal axis shows the normalized frequency (with respect to the symbol rate, $1 / \mathrm{T}$ ) and the vertical axis represents the power spectral density of the mo-

3. For each iteration of the simulation $10^{6}$ equiprobable and independent bits were transmitted. The input variables of the simulation were the relation $\mathrm{Eb} / \mathrm{No}$ to the receiver input and the wavelet type. Meanwhile, the output variables were the bit error probability (BER) and the bandwidth at $99 \%$. The results in Figure 4 correspond to the average of 10 independent iterations for each $\mathrm{Eb} / \mathrm{No}$ value. 
dulated signal (in $\mathrm{W} / \mathrm{Hz}$ ). In this figure it can be seen that the spectrum of the modulated signal is low-pass in character in the three cases shown. Furthermore, the bandwidth occupied by the discrete wavelet Meyer (dmey) is noticeably less occupied than with the Haar wavelet. In addition, the spectral power is distributed much more evenly with the Meyer wavelet.

TABle 2 reports the spectral efficiency results achieved with different wavelet families.

Figure 4 shows the performance curve of VER vs $E_{b} / N_{0}$ for the proposed modulation scheme (WavP 8S-4D). Also shown is the curve corresponding to the 4-QAM scheme (which coincides with the curve of the 2-PAM and 2-PSK schemes).

TABLE 3 shows comparatively the performance of the proposed scheme (WavP $8 \mathrm{~S}-4 \mathrm{D}$ ) with respect to some traditional modulations. The coding gain that appears in the table corresponds to the amount of decibels that can be reduced in $E_{b} / N_{0}$ to achieve a BER $10^{-5}$ with respect to the 2-PAM scheme (Forney, 2005). For the traditional scheme's spectral efficiency shown in the table, the usage of a square root raised-cosain filter (SR-RCF) has been considered, with a roll-off factor of 0.25 (Noguchi, 1986).

\section{Discussion and con- clusion}

\subsection{Results analysis}

Figure 4 shows that the performance against noise of the proposed modulation scheme is higher than the 2-PAM, 2-PSK and 4-QAM modulations, i.e., it requires a lesser relation $E_{b} / N_{0}$ to achieve a certain value of BER. This result shows that it is possible to exceed the performance of traditional uncoded modulation schemes more robustly through
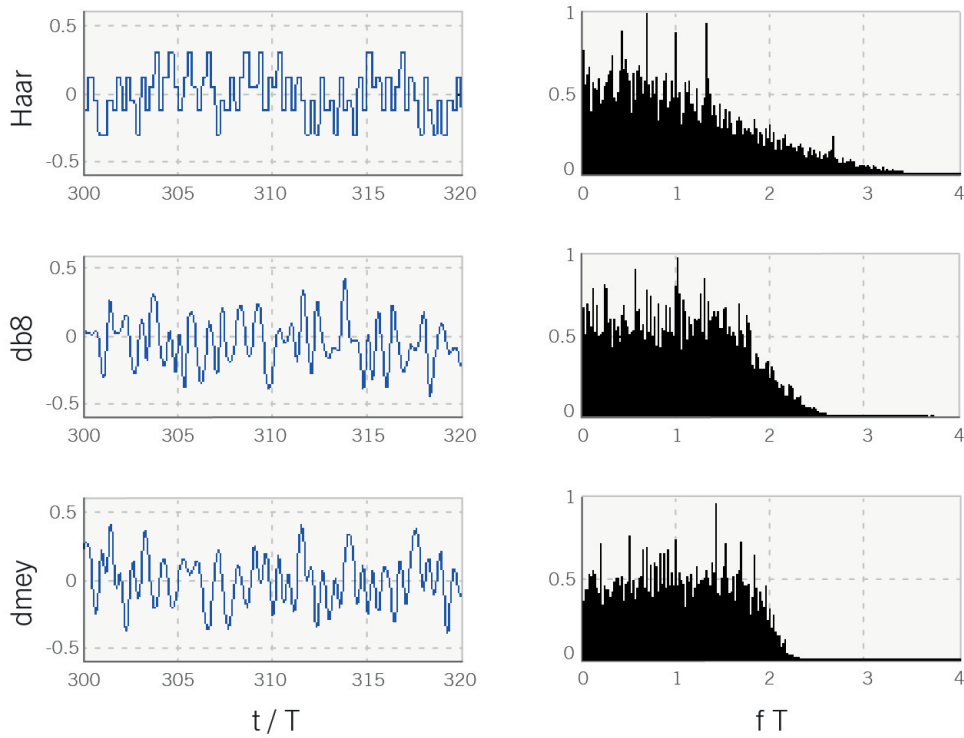

Figure 3. Modulated signal and its spectrum with different wavelet families / Señal modulada y su espectro con diferentes familias wavelet

Table 2. Spectral efficiency with different wavelet families / Eficiencias espectrales con diferentes familias wavelet

\begin{tabular}{ccc}
\hline $\begin{array}{c}\text { Wavelet Family / Familia } \\
\text { Wavelet }\end{array}$ & $\begin{array}{c}\text { Bandwidth }(\mathbf{9 9 \%}) \text { / } \\
\text { Ancho de banda }(99 \%)\end{array}$ & $\begin{array}{c}\text { Spectral efficiency }(\mathbf{b p s} / \\
\mathbf{H z}) / \text { Efciencia espectral (bps/Hz) }\end{array}$ \\
\hline Haar (haar) & $13.40 / T$ & 0.2238 \\
Daubechies 8 (db8) & $2.40 / T$ & 1.2500 \\
Daubechies 45 (db45) & $2.10 / T$ & 1.4285 \\
Symlet 30 (sym30) & $2.14 / T$ & 1.4028 \\
Coiflet 5 (coif5) & $2.30 / T$ & 1.3043 \\
Discrete Meyer (dmey) & $2.12 / T$ & 1.4150 \\
\hline
\end{tabular}

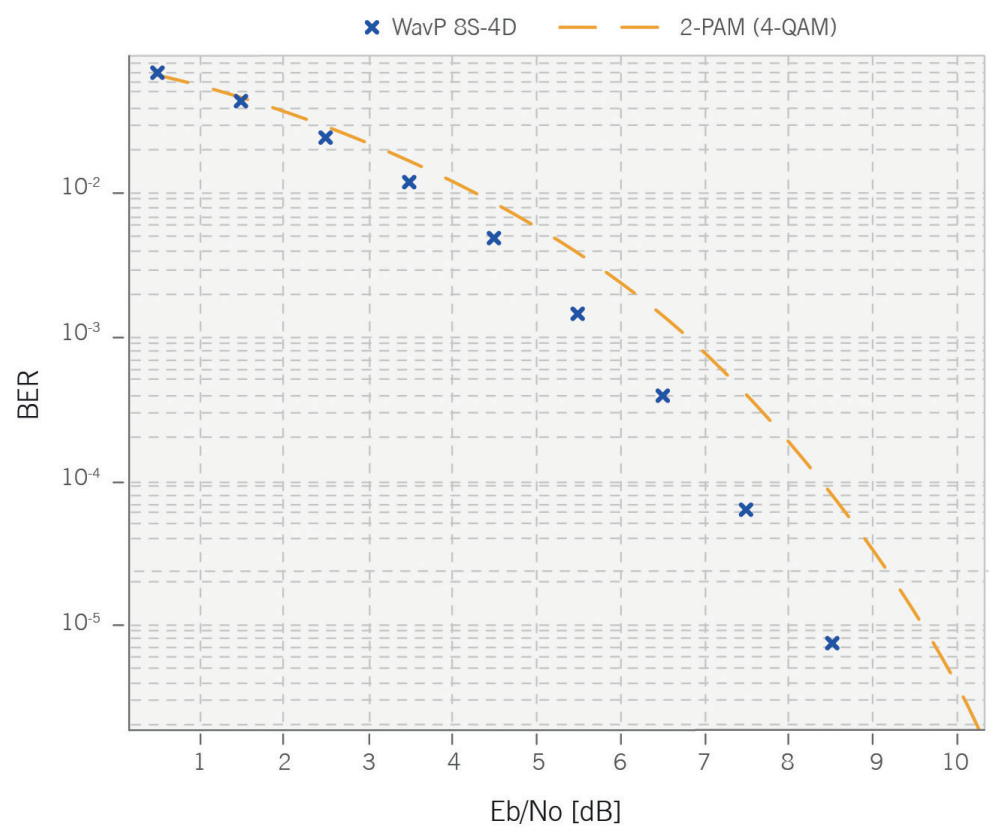

Figure 4. Performance against the noise of the proposed modulation scheme / Desempeño frente al ruido del esquema de modulación planteado 
Table 3. Comparison beytween the proposed and traditional modulation schemes / Comparación entre el esquema de modulación propuesto y los esquemas tradicionales.

\begin{tabular}{ccc}
\hline $\begin{array}{c}\text { Scheme / } \\
\text { Esquema }\end{array}$ & $\begin{array}{c}\text { Spectral effi- } \\
\text { ciency }(\mathbf{b p s} / \mathbf{H z}) / \\
\text { Effiencia espectral (bps/Hz) }\end{array}$ & $\begin{array}{c}\text { Coding gain }(\mathbf{d B}) \\
\text { / Ganancia de codificación } \\
(d B)\end{array}$ \\
\hline 4-QAM & 1.6 & 0 \\
2-PSK & 0.8 & 0 \\
WavP 8S-4D & 1.42 & 1.2 \\
\hline
\end{tabular}

de los esquemas de modulación no codificados tradicionales más robustos, a través del diseño de un espacio de señal en más de dos dimensiones. Adicional a ello, la Tabla 3 muestra que la reducción de la eficiencia espectral del esquema propuesto respecto a 4-QAM (o 2-PAM) no es demasiado grande (alrededor del 11\%), mientras que su ganancia de codificación permite un ahorro cercano al $25 \%$ en potencia de transmisión (para $B E R=10^{-5}$ ). Por otro lado, el desempeño frente al ruido logrado con las diferentes familias wavelet evaluadas es prácticamente similar, mientras que la eficiencia espectral mejora a medida que la duración temporal de la wavelet madre tiende al infinito. En ese sentido, las familias dmey y $d b 45$ producen los mejores resultados en dicho parámetro.

Un aspecto importante a tener en cuenta es la validez teórica de los resultados obtenidos en la simulación, es decir, la existencia de argumentos que sustenten dichos resultados. En primer lugar, el mejor desempeño frente al ruido obtenido con el esquema planteado se puede explicar a partir del hecho de que el espacio de señal diseñado aumenta la relación entre distancia mínima y energía promedio de bit. Si bien, para los esquemas 2-PAM, 2-PSK y 4-QAM se tiene que $d=2 \sqrt{E_{b}}$, en el esquema planteado dicha relación se convierte en $d=2.45 \sqrt{E_{b}}$ (ver apéndice). En segundo lugar, los resultados obtenidos en eficiencia espectral son consecuentes con la restricción de Nyquist para transmisión libre de ISI, la cual afirma que la cota superior para la eficiencia espectral de un espacio de señal de ${ }^{N}$ dimensiones es $\frac{2}{N} \log _{2} M$, donde $M$ es el tamaño de la constelación (Shannon, 1948; Gallager, 1968; Forney et al, 1998). En el esquema planteado, $N=4$ y $M=8$, por tanto la máxima eficiencia espectral posible será $1.5 \mathrm{bps} / \mathrm{Hz}$, lo cual está por encima de los $1.42 \mathrm{bps} /$ $\mathrm{Hz}$ obtenidos con la familia $d b 45$. De esa manera, los resultados expuestos satisfacen las expectativas teóricas.

\subsection{Conclusiones y trabajo futuro}

El esquema de modulación propuesto en este artículo plantea una estrategia novedosa de diseño de un espacio de señal de más de dos dimensiones a partir de un conjunto ortonormal de funciones wavelet. La principal ventaja que ofrece dicho espacio de señal es el aumento de la relación distancia mínima de la constelación - energía promedio de bit, lo que resulta en un mejor desempeño frente al ruido. Por otra parte, la principal desventaja es la disminución de la eficiencia espectral, ya que la utilización de símbolos en 4 dimensiones aumenta el consumo de ancho de banda respecto a un espacio en 1 o 2 dimensiones, pues se transmite mayor cantidad de números reales por unidad de tiempo. the design of a signal space in more than two dimensions. In addition to this, TABLE 3 shows that the reduction of the spectral efficiency of the proposed scheme with respect to 4-QAM (or 2-PAM) is not too large (about $11 \%$ ), while its coding gain allows a saving of close to $25 \%$ in transmission power (for $B E R=10^{-5}$ ). Furthermore, the performance against noise achieved with the different wavelet families evaluated is substantially similar, while the spectral efficiency improves as the temporal duration of the mother wavelet tends toward infinity. In that sense, the dmey and DB45 families produce the best results in this parameter.

An important aspect to consider is the theoretical validity of the results obtained in the simulation, i.e., the existence of arguments that support these results. First, the best performance against noise obtained with the proposed scheme can be explained by the fact that the designed signal space increases the relation between the minimum distance and average bit energy. However, for the 2-PAM, 2-PSK and 4-QAM schedules it is seen that in the proposed scheme this relation becomes $d=2.45 \sqrt{E_{b}}$ (see appendix). Secondly, the spectral efficiency results are consistent with the restriction of Nyquist's transmission free of ISI, which states that the upper bound for the spectral efficiency of a signal space of $\mathrm{N}$ dimensions is $\frac{2}{N} \log _{2} M$, where $M$ is the constellation size (Shannon, 1948; Gallagher, 1968; Forney et al., 1998). In the proposed scheme, $N=4$ and $M=8$, so the maximum possible spectral efficiency is $1.5 \mathrm{bps} /$ $\mathrm{Hz}$, which is above the $1.42 \mathrm{bps} / \mathrm{Hz}$ obtained with the DB45 family. Thus, the above results meet the theoretical expectations.

\subsection{Conclusions and future work}

The modulation scheme proposed in this paper raises a novel design strategy of a signal space of more than two dimensions from an orthonormal set of wavelet functions. The main advantage that this signal space offers is the increase of the minimum distance relation of the constellation - the average bit energy, which results in a better performance against noise. On the other hand, the main disadvantage is the decrease of spectral efficiency, since the usage of symbols in 4 dimensions increases the bandwidth consumption with respect to a space of 1 or 2 dimensions, because a greater amount of real numbers per unit of time is transmitted.

From the design principle of signal space similar to that proposed in this paper, it is possible to define con- 
stellations in $8,16,32, \ldots$ dimensions with $2^{7}, 2^{15}, 2^{31}$ ,... symbols respectively, yielding a better performance against noise and a better spectral efficiency as the number of dimensions increases. However, if the decision rule is based on minimum distance, the complexity of the detection will increase exponentially with the number of dimensions.

\section{Appendiz}

According to TABLE 1, the average energy of a symbol in a constellation can be obtained as:

$$
E_{s}=\mathrm{E}\left[\left\|\mathbf{X}_{k}\right\|^{2}\right]=\sum_{\mathbf{a}_{i} \in \mathcal{A}}\left\|\mathbf{X}_{k}\right\|^{2} \operatorname{Pr}\left\{\mathbf{X}_{k}=\mathbf{a}_{i}\right\},
$$

where $\mathrm{E}[\cdot]$ is the operator of expected value and $\|\cdot\|$ is the operator of the Euclidean norm. If the bits of the message are equiprobable and independent, the average energy of the symbol is equivalent to:

$$
E_{s}=4 \alpha^{2} \text {. (A2) }
$$

Given that each symbol contains 3 bits, the average bit energy will be:

$$
E_{b}=4 \alpha^{2} / 3 .
$$

On the other hand, the minimum distance of the constellation is:

$$
d=2 \sqrt{2} \alpha
$$

When isolating $\alpha$ from equations (A1) and (A2), the relation between $d$ and $E_{b}$ is obtained:

$$
d=\sqrt{6 E_{b}} \cong 2.45 \sqrt{E_{b}}
$$

(A5) SRT
A partir de un principio de diseño del espacio de señal similar al planteado en este artículo es posible definir constelaciones en $8,16,32, \ldots$ dimensiones con $2^{7}, 2^{15}, 2^{31}, \ldots$ símbolos respectivamente, obteniéndose un mejor desempeño frente al ruido y una mayor eficiencia espectral a medida que aumenta el número de dimensiones. Sin embargo, si la regla de decisión está basada en distancia mínima, la complejidad de la detección se incrementará exponencialmente con el número de dimensiones.

\section{Apéndice}

De acuerdo con la TABLA 1, la energía promedio de un símbolo de la constelación se puede obtener como:

$$
E_{s}=\mathrm{E}\left[\left\|\mathbf{X}_{k}\right\|^{2}\right]=\sum_{\mathbf{a}_{i} \in \mathcal{A}}\left\|\mathbf{X}_{k}\right\|^{2} \operatorname{Pr}\left\{\mathbf{X}_{k}=\mathbf{a}_{i}\right\},
$$

donde $\mathbf{E}[\cdot]$ es el operador de valor esperado y $\|\cdot\|$ es el operador de norma Euclidiana. Si los bits del mensaje son equiprobables e independientes, la energía promedio de símbolo equivale a:

$$
E_{s}=4 \alpha^{2} \cdot(\mathrm{A} 2)
$$

Como cada símbolo contiene 3 bits, la energía promedio de bit será:

$$
E_{b}=4 \alpha^{2} / 3 \text {. (A3) }
$$

Por otro lado, la distancia mínima de la constelación es:

$$
d=2 \sqrt{2} \alpha
$$

$\mathrm{Al}$ despejar $\alpha$ de las ecuaciones (A1) y (A2) se obtiene la relación entre $d_{\mathrm{y}} E_{b}$, esto es:

$$
d=\sqrt{6 E_{b}} \cong 2.45 \sqrt{E_{b}} .
$$

(A5) STT

\section{References / Referencias}

Benvenutto, N. \& Cherubini, G. (2002). Algorithms for communication systems and their applications. New York, NY: Wiley.

Cover, M. \& Thomas, J.A. (2006). Elements of information theory (2nd ed.). New York, NY: Wiley.

Daubechies, I. (1988). Orthonormal bases of compactly supported wavelets. Communications on Pure and Applied Mathematics, 4, 909-996.

Daubechies, I. (1992). Ten Lectures on Wavelets. Philadelphia, PA: SIAM.

Daubechies, I. (1990). The wavelet transform, time frequency localization and signal analysis. IEEE Transactions on Information Theory, 36(5), 961-1005.

Forney, G.D. (2005). Principles of digital communications //. Boston, MA: MIT.

Forney, G.D. \& Ungerboeck, G. (1998). Modulation and coding for linear Gaussian channels. IEEE Transactions on Information Theory, 44(6), 2384-2415.

Gallager, R.G. (1968). Information theory and reliable communication. New York, NY: Wiley.

Gallager, R.G. (2006). Principles of digital communications I. Boston, MA: MIT.

Hartley, V.L. (1928). Transmission of information. Bell System Technical Journal, 7, 535-563.

Haykin, S. (2002). Communication systems. New York, NY: Wiley. 
Lindsey, A.R. (1997). Wavelet packet modulation for orthogonally multiplexed communications. IEEE Transactions on Signal Processing, 45(5), 1336-1339.

Lindsey, A.R. \& Medley, M.J. (1996). Wavelet transform and filter banks in digital communications. SPIE Proceedings [Wavelet Applications III], 2762(48). doi:10.1117/12.236018

Livingston, J.N. \& Tung, C. (1996). Bandwidth efficient PAM signaling using wavelets. IEEE Transactions in Communications, 44(12), 1629-1631.

Mallat, S. (1998). A wavelet tour of signal processing. London, UK: Academic Press.

Noguchi, T., Daido, Y., \& Nossek, J. (1986). Modulation techniques for microwave digital radio. IEEE Communications Magazine, 24(10), 21-30.

Nyquist, H. (1928). Certain topics in telegraph transmission theory. Transactions AIEE, 47, 627-644.

Proakis, G. (2000). Digital communications (4th ed.). New York, NY: McGraw-Hill.

Pursley, M. (2005). Introduction to digital communications. Englewood Cliffs, NJ: Prentice-Hall.

Shannon, C.E. (1948). A mathematical theory of communications. Bell System Technical Journal, 27, 379-423, 623-656.

Wornell, G.W. \& Oppenheim, A.V. (1992). Wavelet-based representations for a class of self-similar signals with application to fractal modulation. IEEE Transactions in Information Theory, 38(2), 785-800. 


\section{CURRICULUM VITAE}

Jesús Mauricio Ramírez Viáfara Ingeniero en Electrónica y Telecomunicaciones, y candidato a Magister en Electrónica y Telecomunicaciones de la Universidad del Cauca. Actualmente se desempeña como docente-investigador del Departamento de Telecomunicaciones de la Facultad de Ingeniería Electrónica y Telecomunicaciones de la Universidad del Cauca. Miembro IEEE. / Engineer in Electronics and Telecommunications and Master (c) in Electronics and Telecommunications (Universidad del Cauca). Professor and researcher of the Electronics and Telecommunications Faculty at the Universidad del Cauca. IEEE member.

Harold Armando Romo Romero Licenciado en Matemáticas de la Universidad de Nariño (Pasto, Colombia); Ingeniero Eléctrico, Especialista en Redes y Servicios Telemáticos, y Máster en Electrónica y Telecomunicaciones, de la Universidad del Cauca (Popayán, Colombia). Actualmente se desempeña como docente e investigador en la Facultad de Ingeniería Electrónica y Telecomunicaciones de la Universidad del Cauca. Sus áreas de interés profesional son el procesamiento de señales y las comunicaciones inalámbricas. Es miembro IEEE. / Bachelor degree in Mathematics (Universidad de Nariño, Pasto-Colombia); Engineer in Electronics, Specialist in Networks and Telematic Services, and Master in Electronics and Telecommunications (Universidad del Cauca, Popayán-Colombia). Professor and researcher of the Electronics and Telecommunications Faculty at the Universidad del Cauca. His main interest areas are signal processing and wireless communications. IEEE member. 